\title{
NSGA-II Optimized Multiobjective Predictive Energy Management for Fuel Cell/Battery/Supercapacitor Hybrid Construction Vehicles
}

\author{
Huiying Liu ${ }^{1}$, Xiaoxue Xing ${ }^{1}$, Weiwei Shang ${ }^{1}$, Tianyu $\mathrm{Li}^{2,}$ * \\ ${ }^{1}$ College of Electronic Information Engineering, Changchun University, 130022 Changchun, China \\ ${ }^{2}$ School of Mechanical and Aerospace Engineering, Jilin University, 130025 Changchun, China \\ *E-mail: litianyu@jlu.edu.cn
}

doi: $10.20964 / 2021.04 .24$

Received: 2 December 2020 / Accepted: 20 January 2021 / Published: 28 February 2021

\begin{abstract}
Fuel cell/battery/supercapacitor hybrid vehicles have shown good prospects. Energy management strategies (EMSs) are proposed to solve the complex energy management issues associated with the fuel cells/batteries/supercapacitors of construction vehicles, and to optimised economy and performance. Here, we develop a multiobjective predictive EMS. In the predictive control framework, a nondominated sorting genetic algorithm (NSGA-II) enhances fuel cell and battery durability while minimising economic cost. NSGA-II optimises cost functions in real-time and generates a Pareto front, the data of which are screened by fuzzy logic algorithm to obtain optimal control solutions. Simulations indicated the superior feasibility and effectiveness of our proposed EMS compared to conventional benchmarks. The EMS ensures that fuel cell/battery/supercapacitor hybrid construction vehicles not only receive adequate power under complex working conditions, but also reasonably distribute the power demand among fuel cells/batteries/supercapacitors; this extends the lifespan of these devices and ensures high efficiency.
\end{abstract}

Keywords: fuel cell; hybrid system; energy management; model predictive control; multiobjective optimization.

\section{FULL TEXT}

(C) 2021 The Authors. Published by ESG (www.electrochemsci.org). This article is an open access article distributed under the terms and conditions of the Creative Commons Attribution license (http://creativecommons.org/licenses/by/4.0/). 